\title{
Pelatihan Pembuatan Pupuk Organik Dengan Penggunaan Biostater Pada Kelompok Tani Rukun Makaryo Desa Pereng Mojogedang Karanganyar
}

\author{
Training on Making Organic Fertilizer Using a Biostater in the Rukun \\ Makaryo Farmer Group of Pereng Mojogedang Karanganyar Village
}

\author{
Putri Permatasari $^{1 *}$, Joko Winarno ${ }^{2}$, Sapja Anantanyu ${ }^{3}$, Suwarto $^{4}$, Agung \\ Wibowo $^{5}$
Program Studi Penyuluhan dan Komunikasi Pertanian, Fakultas Pertanian, Universitas Sebelas Maret, Surakarta, Indonesia
*Penulis Korespondensi putripermatasari@staff.uns.ac.id

Riwayat Artikel: Dikirim 9 Juni 2021; Diterima 6 Agustus 2021; Diterbitkan 30 November 2021

\begin{abstract}
Abstrak
Pengetahuan lokal masyarakat diperoleh secara turun temurun atau hasil dari memperhatikan dan mempraktekkan sendiri secara berulang ulang hasil pengalaman orang lain di sekitarnya. Kemanfaatan pengetahuan lokal tersebut secara empiris telah diyakini dan dibuktikan oleh masyarakat dari waktu ke waktu. Pengetahuan lokal dalam bidang pertanian yang dapat dikembangkan yaitu pemanfaatan rumen sapi beserta isinya sebagai biodekompuser dalam proses fermentasi limbah padat ternak sapi menjadi pupuk organik padat fermentasi. Pada rumen sapi terdapat bakteri yang mampu menghancurkan berbagai hijauan yang dimakan sapi. Oleh karenanya, jika bakteri tersebut dapat dikembangbiakkan di luar perut sapi, maka akan dapat digunakan untuk mengatasi limbah padat ternak sapi yang sangat melimpah di pedesaan menjadi pupuk organik padat yang dibutuhkan oleh petani. Kegiatan pengabdian dilakukan pada kelompok tani Rukun Makaryo Desa Pereng Kecamatan Mojogedang Kabupaten Karanganyar yang memiliki potensi limbah ternak pada setiap anggotanya dan belum dimanfaatkan secara optimal. Kegiatan dilakukan dengan pelatihan, pendampingan, monitoring dan evaluasi kemajuan pembuatan pupuk organik padat menggunakan biostater. Tujuan untuk meningkatkan pengetahuan, sikap dan keterampilan anggota kelompok tani dalam pembuatan pupuk organik padat tepat guna. Hasil pengabdian menunjukkan bahwa anggota kelompok tani memiliki antusiasme yang tinggi. Hal ini disebabkan karena pelaksanaan pembuatan pupuk organik dengan biostater mudah dilakukan, biaya murah, tidak membutuhkan peralatan khusus sehingga dapat menghemat pengeluaran biaya usahatani apabila dapat membuat pupuk organik sendiri. Prospek kedepannya anggota kelompok tani dapat memproduksi dalam jumlah banyak sehingga dapat dijual dan menambah nilai ekonomi.
\end{abstract}

Kata kunci: Biodecompuser, Limbah Padat, Pelatihan, Rumen

\begin{abstract}
Local knowledge of the community is obtained from generation to generation or the result of paying attention and practicing themselves repeatedly from the experiences of others around them. The benefits of local knowledge are empirically believed and proven by the community from time to time. Local knowledge in agriculture that can be developed is the use of cow rumen and its contents as a biodecomposer in the process of fermenting cattle waste into fermented solid organic fertilizer. In the rumen of cows there are bacteria that are able to destroy various forages that are
\end{abstract}


eaten by cows. Therefore, if the bacteria can be developed outside the cow's stomach, it can be used to overcome the abundant solid waste of cattle in the countryside into solid organic fertilizer needed by farmers. The service activity was carried out in the Rukun Makaryo farmer group, Pereng Village, Mojogedang District, Karanganyar Regency which had the potential for livestock waste in each of its members and had not been utilized optimally. Activities are carried out by training, mentoring, monitoring and evaluating the progress of making solid organic fertilizers using a biostater. The aim is to improve the knowledge, attitudes and skills of members of farmer groups in the manufacture of effective solid organic fertilizers. The results of the service show that members of the farmer group have high enthusiasm. This is because the implementation of making organic fertilizer with a biostater is easy to do, inexpensive, does not require special equipment so that it can generate farm costs if you can make your own organic fertilizer. Future prospects for members of farmer groups can produce in large quantities so that they can be sold and add economic value.

Keywords: Biodecompuser, Solid Waste, Training, Rumen

\section{PENDAHULUAN}

Pupuk merupakan salah satu komponen penting dalam budidaya padi untuk memenuhi kebutuhan nutrisi agar tanaman tumbuh dengan subur. Permasalahan yang sering dihadapi petani ialah ketersediaan pupuk kimia yang sulit diperoleh bahkan dengan harga yang semakin meningkat. Penggunaan pupuk kimia dalam jangka waktu yang lama dan terus-menerus akan menyebabkan ketergantungan sehingga berakibat pada mengerasnya tanah, tercemarnya air dan keseimbangan alam terganggu karena penggunaan pupuk yang berlebihan. Menurut Roidah (2013) kondisi tersebut disebabkan adanya residu sulfat dan kandungan karbonat yang terkandung dalam pupuk dan tanah bereaksi terhadap kalsium tanah yang menyebabkan sulitnya pengolahan tanah. Aktivitas mikroorganisme di dalam tanah juga terganggu akibat adanya residu herbisida beracun yang menurut Yaasin et al., (2017) residu tersebut dapat membunuh mikroba tanah yang sebenarnya bukan targetnya (non-target microorganism) yang pada akhirnya dapat mempengaruhi siklus hara di dalam tanah.

Permasalahan yang sering terjadi diantaranya: 1) kelangkaan pupuk kimia yang sering dialami petani, 2) harga pupuk tidak terjangkau bagi petani, 3) tempat toko saprodi yang jauh dari tempat tinggal petani sehingga diperlukan alat transportasi yang tidak dimiliki oleh petani gurem (petani miskin). Alternatif permasalahan tersebut bisa diatasi salah satunya menurut Djuarnani et al., (2009) dengan penggunaan pupuk kompos. Yuwono (2009) menyebutkan bahwa pupuk kompos mengandung unsur hara yang tidak ada dalam kandungan pupuk kimia. Pupuk kompos yang diberikan pada tanah mampu memperbaiki sifat fisik tanah yang menurut Bachtiar dan Ahmad (2019) membantu dalam pembentukan agregat atau granulasi tanah serta meningkatkan permiabilitas dan porositas tanah.

Kondisi memprihatinkan soal masalah pupuk, diperlukan adanya inovasi untuk mengatasi ketersediaan pupuk kimia yang minim dengan penggunaan pupuk organik. Pembuatan pupuk organik dapat dilakukan dengan memanfaatkan rumen sapi beserta isinya sebagai biodekompuser dalam proses fermentasi limbah padat ternak sapi menjadi pupuk organik padat. Pembuatan pupuk organik dapat dicampur dengan biostater untuk mempercepat proses fermentasi. Pemanfaatan limbah ternak sapi bisa menjadi salah satu inovasi karena 
ketersediaan bahan yang melimpah (Budiyanto, 2011). Terbatasnya pengetahuan dan keterampilan yang dimiliki anggota kelompok tani menjadikan penggunaan limbah kotoran ternak hanya digunakan dalam bentuk apa adanya. Limbah ternak tersebut dalam bentuk padat dari kotoran sapi yang masih segar. Berikut adalah contoh kegiatan mengumpulkan limbah padat ternak sapi segar.

Gambar 1:

Proses Pengumpulan Limbah Kotoran Ternak

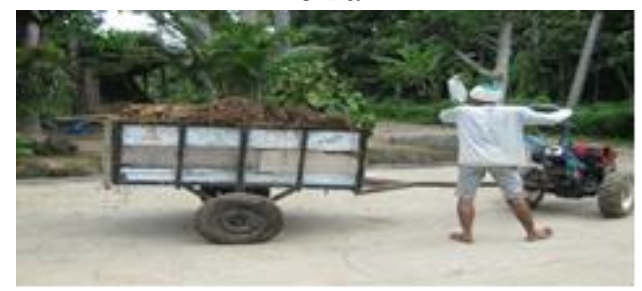

Sumber: Dokumentasi Pribadi

Anggota kelompok tani hanya menggunakan limbah kotoran ternak tanpa melakukan pemrosesan lebih lanjut dan meletakkannya di sekitar kandang atau di halaman rumah sehingga dibiarkan begitu saja hingga mengering. Tanah yang diberi kotoran ternak secara langsung tanpa pemrosesan di awal dapat mempengaruhi proses dekomposisi bahan organik dengan hasil asam-asam organik, senyawa fenol, NH3, CO2, dan panas (Steinfeld, 2006). Apabila didiamkan terlalu lama maka limbah kotoran ternak akan mengalami penurunan kualitas akibat penguapan dan air hujan. Belum lagi ketika musim penghujan maka akan menimbulkan aroma yang tidak sedap dan mengganggu kebersihan lingkungan. Bahan organik dalam kotoran ternak dapat diubah menjadi senyawa organik dan anorganik jika diawal telah dilakukan pengolahan kotoran ternak (Triatmojo et al., 2013).

Kegiatan pengabdian masyarakat dilakukan melalui pelatihan mengenai pemanfaatan limbah ternak sapi menjadi pupuk organik dengan menggunakan biostater. Kegiatan pengabdian masyarakat bertujuan untuk mengubah pengetahuan, sikap, dan keterampilan anggota kelompok tani Rukun Makaryo agar mampu membuat pupuk organik dengan menggunakan biostater dalam mempercepat proses fermentasi. Penggunaan pupuk organik dari limbah ternak sapi yang diolah sendiri mampu membantu petani dalam penghematan pengeluaran biaya usaha tani. Selain itu diharapkan dengan ketersediaan limbah kotoran ternak yang banyak tersedia maka anggota kelompok tani dapat memproduksi dalam jumlah yang banyak sehingga dapat dijual untuk meningkatkan pendapatan rumah tangga petani.

\section{METODE}

Kegiatan pengabdian masyarakat dilakukan di Kelompok Tani Rukun Makaryo Desa Pereng Kecamatan Mojogedang Kabupaten Karanganyar Provinsi Jawa Tengah pada bulan Agustus-September 2020.

Kegiatan pengabdian ini dilakukan dengan pelatihan pembuatan pupuk organik menggunakan biostater di halaman rumah ketua kelompok tani Rukun Makaryo. Berikut langkahlangkah yang dilakukan:

1. Mengidentifikasi masalah yang terjadi yaitu anggota kelompok tani hanya menggunakan limbah kotoran ternak secara apa adanya tanpa pemrosesan lebih lanjut. Sebelum digunakan, kotoran ternak hanya 
dikumpulkan pada sekitar kandang atau dihalaman rumah dan dibiarkan begitu saja sampai mengering.

2. Melakukan pelatihan dengan pembuatan biostater dan pembuatan pupuk organik di hadapan anggota kelompok agar informasi dapat lebih mudah dipahami. Anggota kelompok juga diberi kesempatan untuk dapat mencoba mempraktekkan pada saat kegiatan pelatihan sehingga dapat diterapkan sendiri di rumah masing-masing.

3. Melakukan monitoring dan evaluasi kegiatan pelatihan yang sudah dilakukan. Kegiatan dilakukan dengan kunjungan pada 30 orang peserta. Sebanyak $70 \%$ anggota kelompok tani atau sekitar 21 orang telah mempraktekkan sendiri di rumah. Sedangkan 7 orang lainnya masih mengalami kendala dalam menerapkan inovasi pembuatan pupuk organik dengan biostater yang selanjutnya akan diberikan bimbingan dalam kegiatan kunjungan berikutnya.

\section{HASIL DAN PEMBAHASAN}

Pengetahuan lokal dalam pembuatan pupuk organik belum diaplikasikan secara tepat oleh anggota kelompok tani. Limbah kotoran ternak hanya digunakan secara apa adanya tanpa pemrosesan lebih lanjut. Perlu adanya cara penggolahan pupuk organik secara tepat. Pengomposan merupakan proses penguraian bahan organik secara biologi yang didalamnya memanfaatkan bahan organik sebagai sumber energi. Menurut Dewi \& Trisnowati (2012) bahwa pengomposan diartikan sebagai proses penguraian bahan organik secara biologis oleh mikroba dengan memanfaatkan bahan organik sebagai sumber energi. Pengomposan menurut Dewi et al., (2017) dengan kotoran sapi sangat berpotensial karena memiliki kandungan kimia nitrogen 0,4-1 $\%$, fosfor $0,2-0,5 \%$, kalium 0,1-1,5 \%, kadar air 85-92 \% dan beberapa unsurunsur lain (Ca, Mg, Mn, Fe, Cy, Zn). Hidayati et al., (2011) menyebutkan bahwa kandungan nitrogen dipengaruhi kandungan fosfor, dimana semakin tinggi nitrogen yang terkandung maka multiplikasi mikroorganisme yang merombak akan meningkat. Kandungan fosfor inilah yang dibutuhakan dalam pembelahan sel, pengembangan jaringan dan titik tumbuh tanaman (Widarti et al., 2015).

Limbah padat ternak sapi dalam proses fermentasi dapat dipercepat dengan metode mencampurkan biostarter yang telah disiapkan sebagai pupuk organik. Setiawaan (2010) menyebutkan bahwa penggunaan mikro organisme lokal (MOL) dapat mempercepat pembuatan pupuk organik padat fermentasi. Bahan baku pembuatan biostarter disajikan pada tabel 1 .

Tabel 1:

Bahan Baku Pembuatan Biostarter

\begin{tabular}{|c|c|c|c|}
\hline No & Bahan & $\begin{array}{l}\text { Jumlah } \\
(\mathrm{kg})\end{array}$ & Cara Pembuatan \\
\hline 1. & $\begin{array}{l}\text { Rumen } \\
\text { Sapi }\end{array}$ & $10 \mathrm{~kg}$ & \multirow{8}{*}{$\begin{array}{l}\text { 1.Menyediakan } \\
\text { gentong } \\
\text { tertutup } \\
\text { kapasitas } \\
\text { 20-25 liter. } \\
\text { 2.Menyiapkan } \\
\text { kunir, } \\
\text { kecambah, } \\
\text { lengkuas, } \\
\text { kencur sesuai } \\
\text { dengan } \\
\text { kebutuhan } \\
\text { kemudian } \\
\text { dihaluskan } \\
\text { 3.Memasukkan } \\
\text { semua bahan } \\
\text { ke gentong }\end{array}$} \\
\hline 2. & Bekatul & $5 \mathrm{~kg}$ & \\
\hline 3. & Kecambah & $5 \mathrm{~kg}$ & \\
\hline 4. & Kunir & $1-2,5 \mathrm{~kg}$ & \\
\hline 5. & $\begin{array}{l}\text { Tetes } \\
\text { Tebu }\end{array}$ & 1 liter & \\
\hline 6. & $\begin{array}{l}\text { Jahe, } \\
\text { Lengkuas, } \\
\text { Kencur }\end{array}$ & $\begin{array}{l}\text { Masing- } \\
\text { masing } 1 \\
\mathrm{~kg} \\
\text { yang } \\
\text { dihalusk } \\
\text { an }\end{array}$ & \\
\hline 7. & $\begin{array}{l}\text { Air Leri } \\
\text { (air cucian } \\
\text { beras) }\end{array}$ & 10 liter & \\
\hline 8. & Air Kelapa & 5 liter & \\
\hline
\end{tabular}




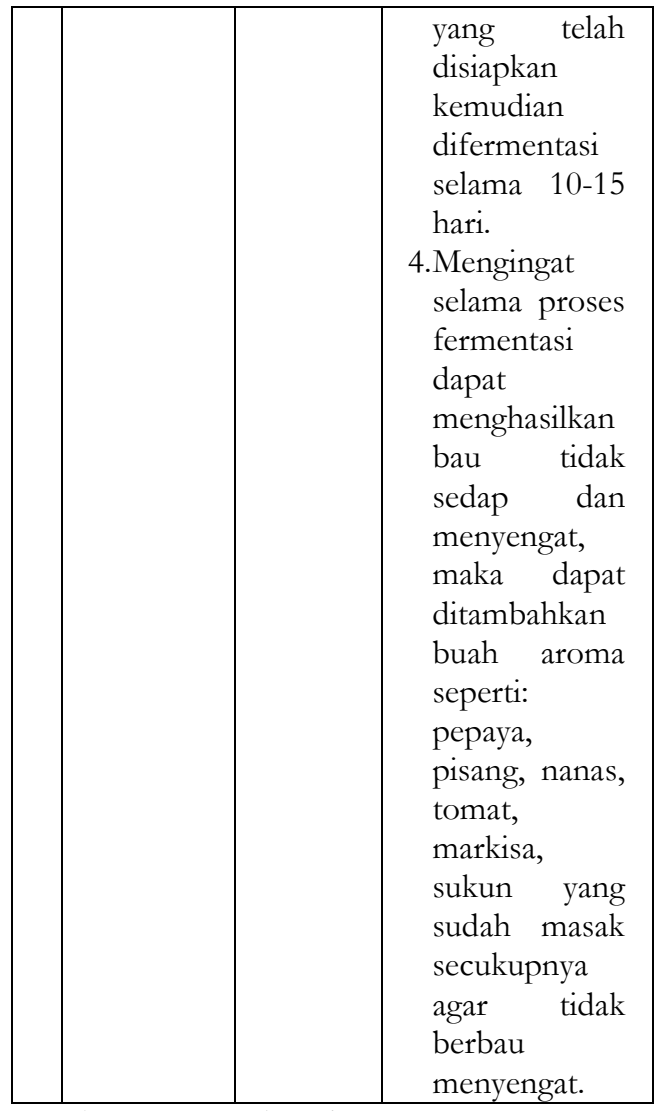

Sumber: Data Sekunder

Contoh gentong yang digunakan untuk tempat pembuatan biostarter disajikan gambar 2.

Gambar 2:

Gentong Feber Glass Berwarna Biru Ukuran 20 Liter

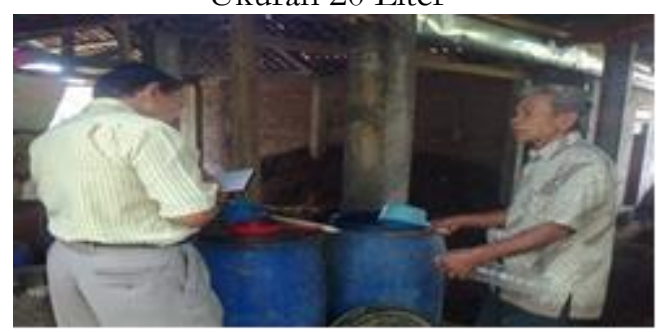

Sumber: Dokumentasi Pribadi

Proses fermentasi pembuatan pupuk organik dilakukan dengan penyiapan limbah padat kotoran ternak sapi. Proses selanjutnya yaitu melakukan pencacahan jika masih terdapat sisa-sisa jerami padat dengan mesih pencacah jerami. Berikut ini contoh proses pembuatan pupuk organik fermentasi yang disajikan pada Gambar 3.

Gambar 3:

Contoh Proses Pembuatan Pupuk Organik Fermentasi

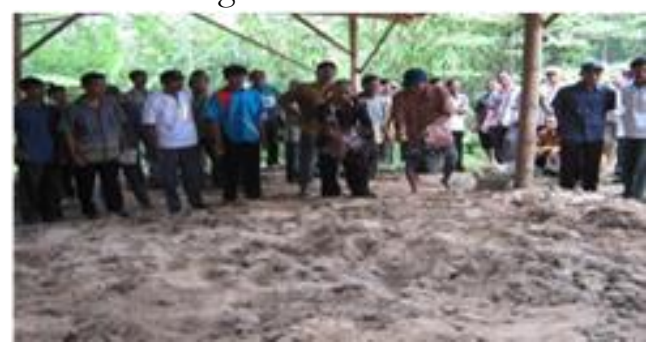

Sumber: Dokumentasi Pribadi

Proses fermentasi juga dipengaruhi oleh kandungan air, menurut Suriawiria (2006) proses tersebut dapat terjadi apabila rasio kandungan air sudah tepat karena peran air itu sendiri sebagai elemen dalam proses biologis selama fermentasi bahan baku. Bahan tambahan yang diberikan sangat menentukan persentase unsur hara pada pupuk organik (Simamora et al., 2006). Bahan tambahan pada proses pembuatan pupuk organik padat berfungsi sebagai penyedia rongga udara yang menyebabkan proses pengomposan akan berlangsung secara optimal. Bahan baku tambahan dalam proses pembuatan pupuk organik padat disajikan pada tabel 2 .

Tabel 2:

Bahan Baku Tambahan dalam Proses Pembuatan Pupuk Organik Padat

\begin{tabular}{|c|c|c|c|}
\hline $\mathrm{No}$ & $\begin{array}{l}\text { Bahan } \\
\text { Baku }\end{array}$ & Jumlah & Cara Pembuatan \\
\hline 1. & $\begin{array}{l}\text { Pupuk } \\
\text { Kandang }\end{array}$ & 1 ton & \multirow{4}{*}{ 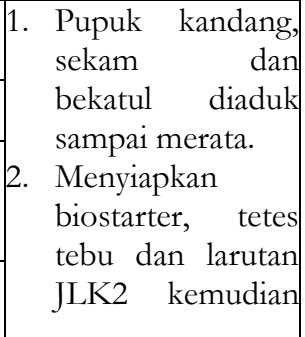 } \\
\hline 2. & Katul & $20 \mathrm{~kg}$ & \\
\hline 3. & $\begin{array}{l}\text { Sekam } \\
\text { Padi } \\
\text { (Brambut) }\end{array}$ & $\begin{array}{l}10 \\
\text { karung }\end{array}$ & \\
\hline 4. & $\begin{array}{l}\text { Induk } \\
\text { Bakteri }\end{array}$ & 2 liter & \\
\hline
\end{tabular}




\begin{tabular}{|c|c|c|c|}
\hline $\mathrm{No}$ & $\begin{array}{l}\text { Bahan } \\
\text { Baku }\end{array}$ & Jumlah & Cara Pembuatan \\
\hline 5. & $\begin{array}{l}\text { Tetes } \\
\text { Tebu }\end{array}$ & 2 liter & $\begin{array}{lr}\text { tambahkan } & \text { air } \\
\text { secukupnya } & \text { dan }\end{array}$ \\
\hline 6. & $\begin{array}{l}\text { JLK2 } \\
\text { (Jahe, } \\
\text { Lengkuas, } \\
\text { Kencur } \\
\text { dan Kunir) }\end{array}$ & 2 liter & 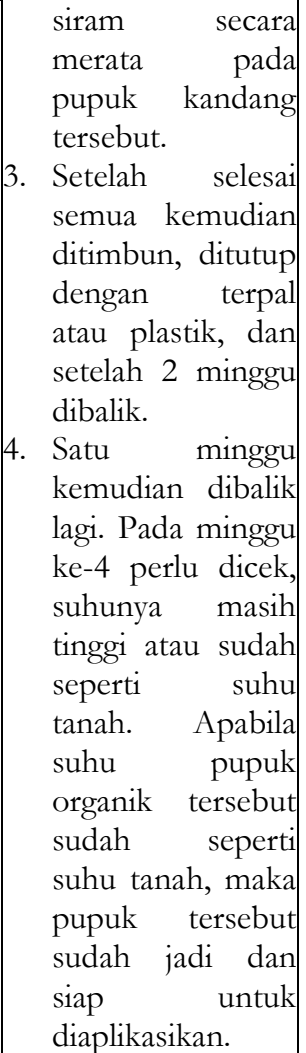 \\
\hline
\end{tabular}

Sumber: Data Sekunder

Pupuk organik padat fermentasi pada saat pengaplikasian harus dilakukan ketika pupuk tersebut sudah jadi. Cara untuk mengetahui pupuk sudah jadi dengan mencelupkan tangan ke dalam pupuk yang hasilnya tidak terasa panas. Hal itu menandakan suhunya sudah seperti suhu tanah. Murbandono (1995), Djuarnani et al., (2009), Simamora \& Salundik (2008), Djaja (2008) menyebutkan bahwa karakteristik pupuk organik padat fermentasi yang sudah siap diaplikasikan dicirikan bila suhu pupuk sudah seperti suhu udara. Proses pengomposan akan membutuhkan waktu yang lebih lama apabila pupuk organik padat terlalu lembab dan terlalu rendah maka efisiensi degredasi akan menurun (Pandebesie \& Rayuanti, 2013).

Penggunaan pupuk organik padat fermentasi mampu mengatasi defisiensi hara, mampu menyediakan hara secara cepat dan memliki bahan pengikat sehingga kandungan pupuk bisa langsung terserap oleh tanaman (Meriatna et al., 2019).

Pupuk organik padat fermentasi selain memiliki kelebihan juga memiliki kelemahan jika kurang tepat dalam pengaplikasiannya yang akan menyebabkan tanaman mati. Proses fermentasi jika masih dominan terjadi menyebabkan pupuk yang akan diaplikasikan menghasilkan panas di dalam tanah. Kondisi tersebut akan menyebabkan tanaman mati karena proses fermentasi yang menyentuh akar tanaman. Umumnya terjadi di lahan kering dan sangat langka ditemukan pada lahan padi sawah.

Kegiatan pengabdian masyarakat yang dilakukan membawa perubahan pengetahuan, sikap dan keterampilan anggota kelompok tani Rukun Makaryo. Aspek perubahan pengetahuan dilihat dari sebanyak 24 orang dari 30 orang peserta yang belum mengetahui cara pembuatan pupuk organik, setelah mengikuti pelatihan maka seluruh peserta akhirnya memahami cara pembuatan pupuk organik. Aspek perubahan sikap dapat dilihat saat pendampingan peserta yang tadinya menganggap pembuatan pupuk organik sebagai suatu hal yang sulit akhirnya setelah mencoba menganggap sebagai suatu hal yang mudah untuk dikerjakan. Perubahan keterampilan petani terlihat ketika kegiatan kunjungan yang dilakukan di rumah anggota kelompok sebanyak 21 orang dari 30 orang peserta sudah mampu 
menerapkan dan mengaplikasikan pupuk organik pada lahan pertaniannya sendiri.

Setelah mendapatkan pelatihan mengenai pembuatan pupuk organik dengan menggunakan biostater maka rencana tindak lanjut untuk menjaga keberlangsungan kegiatan pembuatan pupuk organik akan dibuat kelompok pengolah pupuk organik sehingga dapat dijual dan memberikan dampak ekonomis terhadap pendapatan masyarakat. Salah satu rencana tindaklanjut ke depannya dapat dilakukan dengan pendampingan dalam teknik pemasaran pupuk organik hasil produksi kelompok tani Rukun Makaryo agar dapat dijual secara lebih luas.

\section{KESIMPULAN}

Kegiatan pengabdian dilakukan pada bulan Agustus-September 2020 di Kelompok Tani Rukun Makaryo, Desa Pereng Kecamatan Mojogedang Kabupaten Karanganyar. Kegiatan dilakukan dengan pelatihan pendampingan, monitoring dan evaluasi kemajuan program pembuatan pupuk organik padat menggunakan biostater. Dengan pelatihan maka anggota kelompok dapat melihat secara langsung proses pembuatan dan bisa mencoba praktek sehingga nantinya dapat diterapkan sendiri pada lahan usahataninya masing-masing.

Kegiatan pengabdian masyarakat mendapat respon yang baik dari petani dilihat dari antusiasme peserta dalam mengikuti kegiatan. Hal ini disebabkan karena pelaksanaan mudah, biaya murah, tidak membutuhkan peralatan khusus sehingga dapat menghemat biaya usahatani. Prospek kedapannya anggota kelompok tani dapat memproduksi pupuk organik dalam jumlah banyak sehinga dapat dijual dan menambah nilai ekonomi. Kegiatan pengabdian masyarakat tidak hanya mengubah pengetahuan, sikap, keterampilan anggota kelompok Rukun Makaryo namun didalamnya juga terdapat kegiatan pemberdayaan agar mampu mengoptimalkan aksesibilitasnya sehingga dapat meningkatkan aspek ekonomi petani dengan penggunaan pupuk organik buatan sendiri dalam kegiatan usahataninya.

\section{DAFTAR PUSTAKA}

Bachtiar, B., \& Ahmad, A. H. (2019). Analisis Kandungan Hara Kompos Johar Cassia siamea dengan Penambahan Aktivator Promi. Bioma: Jurnal Biologi Makassar, 4(1), 68-76. https://doi.org/10.20956/bioma. v4i1.6493

Budiyanto, K. (2011). Tipologi Pendayagunaan Kotoran Sapi dalam Upaya Mendukung Pertanian Organik di Desa Sumbersari Kecamatan Poncokusumo Kabupaten Malang. Jurnal GAMMA, 7(1), 42-49. http://ejou rna l.u mm.ac.id/index.php/gamma/Mo ch. Agus Krisno Budiyanto a rticle/view/1 420

Dewi, N., Setiyo, \& Nada. (2017). Pengaruh Bahan Tambahan pada Kualitas Kompos Kotoran Sapi The Effect of Bulking Agent on The Quality of Compost Cow Manure. Jurnal BETA (Biosistem Dan Teknik. Pertanian), 5(1), 76-82. https://ojs.unud.ac.id/index.php/ 
beta/article/view/25566

Dewi, Y.S., \& Tresnowati. (2012).

Pengolahan Sampah Skala Rumah

Tangga Menggunakan Metode

Composting. Jurnal Ilmiah Fakultas

Teknik LIMIT'S, 8(2), 35-48. https://www.lppm.usni.ac.id/jurn al/yusrianikomposting.pdf

Djaja, W. (2008). Langkah Jitu Membuat Kompos dari Kotoran Ternak dan Sampah. Jakarta: PT. Agro Media Pustaka.

https://agromedia.net/katalog/lan gkah-jitu-membuat-kompos-darikotoran-ternak-sampah/

Djuarnani, N., Kristian, A., \& Budi, S. (2009). Cara Cepat Membuat Kompos. Jakarta: PT. Agro Media Pustaka. https://agromedia.net/katalog/car a-cepat-membuat-kompos/

Hidayati, Y.A., Kurnani, A., Marlina, E.T., \& Harlia, E. (2011). Kualitas Pupuk Cair Hasil Pengolahan Feses Sapi Potong Menggunakan Saccharomyces cereviceae. Jurnal Ilmu Ternak, 11(2), 104-107. https://doi.org/10.24198/jit.v11i2 .387

Meriatna, M., Suryati, S., \& Fahri, A. (2019). Pengaruh Waktu Fermentasi dan Volume Bio Aktivator EM4 (Effective Microorganisme) pada Pembuatan Pupuk Organik Cair (POC) dari Limbah Buah-Buahan. Jurnal Teknologi Kimia Unimal, 7(1), 13-29. https://doi.org/10.29103/jtku.v7i 1.1172

Murbandono, L. (1995). Membuat Kompos. Jakarta: Penebar Swadaya. http://www.ampl.or.id/digilib/rea d/membuat-kompos-edisirevisi/549

Pandebesie, E.S., \& Rayuanti, D.
(2013). Pengaruh Penambahan Sekam pada Proses Pengomposan Sampah Domestik. Jurnal Lingkungan Tropis, 6(1), 31-40. 10.22146/jsv.29301

Roidah. (2013). Manfaat Penggunaan Pupuk Organik untuk Kesuburan Tanah. Jurnal Universitas Tulung Agung BONOROWO, 1(1), 30-42. https://doi.org/10.36563/bonoro wo.v1i1.5

Setiawan, B.S. (2010). Membuat Pupuk Kandang Secara Cepat. Jakarta: Penebar Swadaya. https://pustakaaceh.perpusnas.go. id/detail-opac?id $=38942$

Simamora, S., \& Salundik. (2008). Meningkatkan Kualitas Kompos. Jakarta: PT. Agro Media Pustaka. https://agromedia.net/katalog/m eningkatkan-kualitas-kompos/

Simamora, S., Salundik, \& Wahyuni, S. (2006). Modul Pelatihan, Pengolahan Limbah Peternakan Ramah Lingkungan dengan Teknologi Tepat Guna untuk Pengembangan Agribisnis Produksi Gas Bio, Pupuk Organik Padat/Cair). Bogor: Institut Pertanian Bogor.

Steinfeld, H. (2006). Livestock's Long Shadow. Rome: FAO. http://www.fao.org/3/a0701e/a0 $701 \mathrm{e} 00 . \mathrm{htm}$

Suriawiria, U. (2006). Budidaya Jamur Tiram. Yogyakarta: Kanisius. ISBN: 978-979-21-0196-6

Triatmojo, S., Yuni, E., \& Nanung, A.F. (2013). Bahan Ajar Teknologi Penanganan Limbah Peternakan Dasar. Yogyakarta: Universitas Gadjah Mada.

https://repository.ugm.ac.id/id/e print $/ 273197$

Widarti, B.N., Wardhini, W.K., \&

Pelatihan Pembuatan Pupuk Organik Dengan Penggunaan Biostater Pada Kelompok Tani Rukun Makaryo Desa 
Sarwono, E. (2015). Pengaruh

Rasio C/N Bahan Baku pada

Pembuatan Kompos dari Kubis

dan Kulit Pisang. Jurnal Integrasi

Proses, 5(2), 75-80.

http://dx.doi.org/10.36055/jip.v5 i2.200

Yaasin, R., Putra, A., Wiharso, D., \& Niswati, A. (2017). Pengaruh Pengolahan Tanah dan Aplikasi Herbisida terhadap Kandungan Asam Humat pada Tanah Ultisol Gedung Meneng Bandar Lampung. Jurnal Agrotek Tropika, 5(1), 51-56. http://dx.doi.org/10.23960/jat.v5i 1.1847

Yuwono, D. (2009). Kompos. Jakarta: Penebar Swadaya. ISBN: 979-489951-8 